\title{
Effects of Digital Short Stories on the Development of Listening Skills: An Action Research ${ }^{1}$
}

Los Efectos de las Historias Digitales Cortas en el Desarrollo de Habilidades de Escucha: Una Investigación Acción

\section{Zeynep Çetin Köroğlu²*}

Bayburt University, Turkey

${ }^{1}$ Received: August $8^{\text {th }}$ 2019/ Accepted: April $1^{\text {st }} 2020$

2 zeynepcetin86@gmail.com 


\section{Abstract}

The present research aimed to find out whether digital short stories can improve language learners' listening skills. The purpose of this study was to figure out student teachers' perceptions of digital short stories' implementation into language classrooms. Specifically, the current research aimed to investigate whether digital short stories are useful to develop language learners' listening skills in English. The research is action research in design. The study used pretest and post-test, a written structured interview to collect data and it included both quantitative and qualitative components. The interview consisted of six open-ended questions. Achievement tests and t-test were used to analyse quantitative data. On the other hand, content analysis was used to analyse qualitative data. The data were collected in 2016-2017 academic years at a state university, Turkey. Participants were preparatory class students of English language teaching department of the university. In the treatment process, digital short stories were used for eight weeks, which were written by various famous American authors and voice recorded by American native speakers of English. Additionally, weekly worksheets and hand-outs were prepared by the researcher. Results showed that digital short stories provide satisfactory content, supports vocabulary learning, improves language learners' listening skills, helps participants to gain familiarity with complex grammar structures and makes students more familiar with different cultures. Furthermore, participants were satisfied with digital short stories and they thought these digital stories are useful to improve their listening skills.

Keywords: Digital short story; English language teaching; listening skills; student-teacher.

\section{Resumen}

La presente investigación tuvo como objetivo descubrir si las historias cortas pueden mejorar las habilidades auditivas de los estudiantes de idiomas. El propósito de este estudio fue descifrar las percepciones de los estudiantes-profesores sobre la implementación de historias digitales cortas en el aula. Específicamente, el objetivo es investigar si los cuentos digitales son útiles para desarrollar las habilidades auditivas de los estudiantes de inglés. El estudio es investigación acción en el que se implementaron unas herramientas de recolección de datos, como: un pre-test y un post-test, una entrevista estructurada y se incluyó tanto componentes cuantitativos como cualitativos. La entrevista consistió en seis preguntas abiertas. Las pruebas de rendimiento y la prueba $t$ se utilizaron para analizar datos cuantitativos. Por otro lado, el análisis del contenido se usó para analizar los datos cuantitativos. Los datos se recolectaron en el año académico 2016-2017 en una universidad estatal en Turquía. Los participantes fueron estudiantes de la clase preparatoria del departamento de enseñanza de inglés de la universidad. En el proceso, las historias digitales cortas se usaron por ocho semanas, las cuales fueron escritas por varios autores americanos famosos y grabadas por hablantes nativos americanos de inglés. Además, hojas de trabajo y folletos fueron preparados por el investigador. Los resultados mostraron que las historias digitales cortas proporcionan un contenido satisfactorio, apoyan el aprendizaje de vocabulario, mejora las habilidades de escucha de los estudiantes de lengua, ayuda a los participantes a ganar familiaridad con estructuras gramaticales complejas y hace 
que los estudiantes estén mas familiarizados con diferentes culturas. Además, los participantes quedaron satisfechos con las historias digitales cortas y ellos opinaron que las historias son útiles para mejorar sus habilidades de escucha.

Palabras clave: historias digitales cortas, enseñanza de inglés, habilidades de escucha, estudiante-profesor.

\section{Resumo}

A presente pesquisa teve como objetivo descobrir se as histórias curtas podem melhorar as habilidades auditivas dos estudantes de idiomas. O propósito deste estudo foi decifrar as percepções dos estudantes-professores sobre a implementação de histórias digitais curtas na sala de aula. Especificamente, o objetivo é pesquisar se os contos digitais são úteis para desenvolver as habilidades auditivas dos estudantes de inglês. $\mathrm{O}$ estudo é pesquisa ação no que se implementaram umas ferramentas de coleta de dados, como: um pré-teste e um pós-teste, uma entrevista estruturada e se incluiu tanto componentes quantitativos como qualitativos. A entrevista consistiu em seis perguntas abertas. As provas de rendimento e a prova $t$ se utilizaram para analisar dados quantitativos. Por outro lado, a análise do conteúdo foi utilizada para analisar os dados quantitativos. Os dados se coletaram no ano acadêmico 2016-2017 em uma universidade estadual na Turquia. Os resultados mostraram que as histórias digitais curtas proporcionam um conteúdo satisfatório, apoiam a aprendizagem de vocabulário, melhora as habilidades de escuta dos estudantes de língua, ajuda os participantes a ganhar familiaridade com estruturas gramaticais complexas e faz que os estudantes estejam mais familiarizados com diferentes culturas. Além disso, os participantes ficaram satisfeitos com as histórias digitais curtas e eles acharam que as histórias são úteis para melhorar suas habilidades de escuta.

Palavras chave: histórias digitais curtas, ensino de inglês, habilidades de escuta, estudanteprofessor, estudantes universitários 


\section{Introduction}

he field of education has been revolutionized and reshaped by technology. Unexceptionally, language pedagogy has been constantly changing due to technological development. Nowadays, language learners can easily access literary texts, novels, short stories, poems or teaching materials. Technological developments have changed the form of these elements as well. For instance, novels are voice recorded by native speakers, so EFL learners can easily download and access to these electronic versions wherever they want. According to Kledecka Nadera (2001), reading texts can be transformed through computer software programs, which enable to add sound, graphics, photographs, animations, video, a direct link and reference to dictionaries for better understanding and comprehension. These computer technologies make the target language more alive and concrete (Warschauer \& Healey, 1998). Additionally, all of these technologies advance language learners' skills such as listening, speaking, reading, writing, grammar, pronunciation, and vocabulary. In this respect, new forms of teaching materials lead to new teaching styles in language classrooms. Brown's research (2001) reveals that students mostly spend their time at school through listening. Therefore, language teachers need to provide them with skills and strategies for effective listening skills.

Krashen (1985) discusses that people acquire language by understanding the linguistic information they hear. So, language acquisition is achieved mostly through receiving understandable input and listening ability is vital in achieving understandable language input. Similar discussion is made by Piaget that infants learn language items by hearing and basic reflexes in sensorimotor stage in 0-2 year (Piaget, 1970). Along the same line with these theories, when children's developments are observed, it is seen that they first listen and then start to speak. They speak before they read and as the last skill writing comes after reading. This sequence can be explained with Piaget's (1970) cognitive developmental model. It is clear that all among the language skills, listening is the first one to develop (Lundsteen, 1979). Similar to children's first language development, foreign language learners need to listen in a conscious and deliberate way, before they speak (Anderson \& Lynch, 2003).

At this point, it needs to be clarified that defining listening as a passive skill would be misleading (Anderson \& Lynch, 2003; Lindslay \& Knight, 2006). In the communication process, the listener as receiver decodes the message through linguistic and nonlinguistic knowledge, understands, answers and replies that all these roles prove it is an active skill. According to Güleç and Durmuş (2015), the listener combines and organizes what he/she heard with his/her background knowledge and structures the information mentally. It is clear that hearing is passive but listening is an active process (Kline, 1996). The importance of listening skills in language classrooms may be listed as follows; 
- Input is provided through listening skills and learning begins with understanding input at the right level. Thus, it is crucial to lead learning.

- Interaction is a must to achieve understanding in language classrooms and spoken language provides interaction to both speaker and listener.

- Understanding authentic spoken language is a challenge for language learners because they hear the language as native speakers use it.

- Language teachers can easily draw learners' attention to new vocabularies, structures, and interaction patterns through listening practices (Rost, 1994).

The importance of listening skills should not be disregarded by teachers in language classrooms because it is crucial to develop other language skills and somehow they are bonded to each other (Hansan, 2000, Rost, 2002, Wolvin \& Coakley, 1997, Smidt \& Hegelheimer, 2004). If an example is needed to be given, better speaking skills can be taught through listening skills because people cannot communicate face to face unless both types of skills are developed together (Rost, 2002). As Hansan (2000) stated that "listening comprehension provides the right conditions for language acquisition and development of other language skills" (p.138).

Even though listening skills have crucial roles, these skills are often neglected and poorly taught in language classrooms (Ciğerci \& Gültekin, 2017). Related researches show that language learners perceive listening as one of the most difficult skills in which to improve (Graham, 2006). Listening is a complicated process in nature which requires background knowledge, linguistic awareness and positive aptitude to interpret the input with natural speed (Buck, 2001). Related researches indicate that there are various problems related to listening skills. Problems with listening skills are commonly noted as difficulty in the monitoring of understanding. Listening process consists of various steps. Firstly, and yet crucially sounds should be heard clearly by the listener. The second step is recognizing the sounds that are parts of a word. Thirdly, words are needed to connect to their meaning. As the fourth step, listeners need to remember what each word means in the target language. As the final step, the listener needs to understand the concept of all of the words together (Mendelson, 1994). İbtisam Ali (2016) states that three aspects are the most problematic in listening exercises. Firstly, some language learners may have difficulty to understand everyday speech with different accents. They may misunderstand certain sounds. Secondly, some language learners may lack fundamental listening skills and strategies to get the necessary information for completing the given task.

The last possible problem is that listening content may be culture-specific or include complex language terms to grasp the meaning. Additionally, processing of incoming information during a speech takes place at the pauses. During the speech, listeners create mental messages which are stored in their brain. Storage of mental message is 
known as false recognition memory, which is one of the most important features of listening skills (Rivers, 1992). According to Cook (1996), memory limitations are as important factors as learners' ability to understand the L2 speech because all listening comprehension relies on storing and processing of information in the mind. That's to say, language learners experience difficulties in listening because of processing information in the second language. Language learners generally face problems such as poor monitoring of understanding, problems in speech segmentation, recognizing familiar vocabularies in the speech flow and inability to combine background knowledge with newly received information during the speech (Ofsted, 2011). Another problem with listening skills in a foreign language is related to the teaching phase of listening skills.

At this point, Mendelson (1994), suggests three possible reasons why listening skills are neglected and poorly taught. The first reason is that listening skills are considered as they can be improved when language learners listen to their teachers during teaching. The second reason is that language teachers do not feel comfortable about teaching listening skills because it requires additional efforts and expertise. When an EFL learner exposed to a traditional audio recording in language classroom (which provides only the sound), the listener is limited in reception (Gough, 1993). In this vein, as the last reason, traditional listening materials are not adequate and efficient to teach listening skills in language classrooms (Mendelson, 1994, Gough, 1993). Listening exercises become principally comprehension tests which generally requires the grasping of specific details rather than the general meaning of the given text. This kind of listening activity makes students feel less successful if they feel that they understand a few sets of vocabulary of listening materials. Additionally, research carried out by Ofsted (2011), revealed that language teachers tend to use textbooks as sources of listening materials and activities. Even though, language teachers have begun to use internet as a source for listening activities recently, without effective and necessary pedagogical strategies, internet-based sources for listening skills development will not be as effective as pedagogically designed listening materials (Jones, 2008).

However, listening exercises can be enriched by combining them with literary texts and current fruitful and useful technological tools. Thus, literary texts especially short stories appeal language learners' attention, emotion, interest, and their imaginary world. In addition to this, short stories make language learners able to think from other perspectives and develop their sense of aesthetics. Additionally, short stories support language learners reading abilities, motivate them to participate in exercises and enable language learners to discover different cultures through context. With the help of developing technologies, it is easy to find and create various formats of literary texts. Digital tools have been used to convert literary texts into more colourful, enjoyable and appealing sources for language classrooms. Although there are numerous studies which show the use of short stories and computer usage in L2 education, short stories' 
integration into computer technologies in L2 education is quite limited. At this point, the current research aims to integrate digital short stories into listening practices in language classrooms. The current study additionally investigates language learners' perspectives of this new trend through the use of semi-structured interviews. The present research is guided by the following research questions;

1. Do digital short stories have any effects on the development of preparatory class students' listening skills?

2. Whether preparatory class students' have a positive attitude towards the use of digital short stories for listening exercises?

\section{Related Research}

Digital short stories have potential benefit to develop language skills but there are few studies on their effects and usage especial in listening skills (Ciğerci \& Gültekin, 2017). A research was carried out by Yllmaz (2015) in Turkey. In this empirical study, the researcher aimed to scrutinize the use of short stories via computer technologies in teaching and learning the English language. Researcher's objective is two-fold: to examine how short stories could be used through computer programs in teaching and learning English and to collect data about students' perceptions of this technique via semi-structured face-to-face interview. In the scope of the study, three different computer programs (Jing, Screencast, and Instant Messaging) and three short stories (A Dead Woman's Secret by Guy de Maupassant, Eveline by James Joyce, Hills like White Elephants by Ernest Hemingway) were used. During the study 35 ELT students studying at a state university in Turkey carried out a number of pre-reading/ writing, while-reading/writing, and post-reading/writing activities and tasks suggested by different scholars in the field. The researcher used content analysis of the 12 semistructured interviews. The results revealed that the implementation of short stories through computers in language classrooms have some very positive effects on learners' language learning process: drawing attention, raising curiosity, cooperation and giving/receiving feedback, improving reading and writing skills, and increasing L2 motivation. It can be inferred from the results that digital short stories are quite effective to develop listening skills of foreign language learners. In addition to this, these digital stories enable language learners to develop reading and writing skills as well. Another research is carried out by Hassen (2016).

The purpose of his study was to measure the effects of using podcasts in enhancing EFL learners' listening comprehension. For the sake of accepting or rejecting the hypothesis, which imply that podcasts will help EFL learners to develop their listening comprehension, a questionnaire was distributed to fifty (50) third-year students of English at Mohamed Khader of Biskra, in addition to an interview that was conducted 
with four (4) oral expression teachers from the English department of the same university. The results showed that podcasts can help EFL learners to enhance their listening comprehension. Furthermore, the findings revealed that video podcasts are more effective than audio podcasts in terms of listening development. Thus, the use of visual and verbal inputs contributed to develop better listening comprehension skills of language learners in terms of the gist and contextual guessing. Additionally, with the help of video podcasts students were able to recall information when sounds aided with visuals.

Another research was carried out by Ciğerci and Gültekin (2017) about digital short stories' effect on listening skills development. They aimed to investigate the effect of digital stories on the Turkish (mother language) listening skills of fourthgrade students. Mixed methods were conducted and both qualitative and quantitative data were collected after 8 weeks' treatment process. The results revealed that a significant difference was found between the post-test listening comprehension scores for the experimental and control groups. The qualitative data of the research revealed that digital short stories help to create more engaging and motivating classrooms for listening skills development. Abidin et. al. (2011) carried out a research to investigate the effects of digital stories on the listening comprehension skills of pre-school students in a foreign language learning context. The experimental group watched digital short stories and at the end of the research post-test results indicate a significant difference between the experimental group and the control group. One other research was carried out by Verdugo and Belmonte (2007) to understand whether ICT enhanced short stories effective on 6 years old participants' understanding of spoken English.

The findings of the research indicated that the experimental group outperformed control group in final test administration. The results indicate that digital short stories draw language learners' attention regardless of their age by providing more realistic features of target language. Thus, multimedia technologies include not only linguistic features but also paralinguistic features such as body language, mimicry, and gestures (Verdugo \& Belmonte, 2007). A master thesis was carried out by Jimmy (2013) to investigate the effectiveness of digital stories on listening skills development. In study, participants were exposed to digital stories one a week and the treatment phase lasted for eight weeks. Before watching digital short stories, forty pictures which were taken from digital stories were shown to participants as pre-test. After they watched the same pictures were shown again as post-test. Researcher wanted participants to speak and write about the pictures. Results of the study showed that participants' listening skills improved and they gave positive feedback about the administration. Digital stories promote participants' imagination and make them more motivated by combining visuals and audio (Ciğerci and Gültekin, 2017). When considering age of the participants in Jimmy's research who were year three students of a public school, they had less concentration span. However, the researcher stated that digital stories motivated the participants. 
Tamjid and Hassanzadeh (2012) also investigated impact of digital stories on listening skills development in their quasi experimental research. Totally, forty, 11-14 year- old female students participated in that study. An experimental group with 20 students were exposed to digital stories and a control group with 20 students were treated in traditional listening materials and both groups were tested in terms of listening skills development. Findings of the study showed that experimental group outperformed in the final test. In their research, combination of text, sounds and images provide rich, stimulating and authentic learning environment to experimental group. Besides, students had chance to receive target language through multiple channels such as audio, video and graphics.

According to Küçükoğlu and Sarıçoban (2011) short stories are the most preferred ones in language classrooms that digital versions offer more effective learning opportunities with the help of developing educational technologies. In addition to these studies, other researchers have investigated digital storytelling's effects on other language areas such as reading, writing and speaking skills in foreign language teaching and mother tongue development. These studies on the development of writing skills in foreign language education (Abou Shaban, 2015; Abdollahpour \& Asaszadeh, 2012; Chuang, Kuo, Chiang, Su \& Chang, 2013), and studies on the development of writing skills in mother language education (Baki, 2015; Foley, 2013; Çıralı, 2012).

\section{Method}

The purpose of this study was to find out student teachers' perceptions towards digital short stories' implementation into language classrooms. Specifically, the present research aimed to investigate whether digital short stories were useful to develop student teachers' listening skills in English. The current research was designed in the form of an action research and one group pre-test and post-test design were utilized. The pre-test was administered before the treatment phase which lasted 8 weeks and then post-test was administered. Additionally, the study used a written structured interview to collect qualitative data. Totally, 24 student teachers of English participated in the study, who were 7 males and 17 female students of the English language teaching department at a university. The participants' ages varied from 18 to 21 . It was supposed that participants have the same educational background because they have studied at state schools in Turkey. Additionally, participants' listening proficiency levels were supposed to be nearly the same that was concluded through their listening proficiency tests administered at the beginning of the term. 


\section{Procedure}

Vandergrift's pedagogical cycle $(2004,2007)$ was utilized in the current study. The treatment process lasted 8 weeks. Each week, a digital short story was selected as an authentic listening material. Suitable for Vandergrift's pedagogical cycle pre-activities were prepared such as mind-maps, brainstorming, vocabulary lists, visuals related with the story, highlighting necessary key vocabulary words. These pre-listening activities were used to activate students' prior knowledge and encourage them before the listening phase. In the listening phase, students were expected to complete assigned tasks such as while listening and after listening. Pre-prepared handouts were given to students. As the last phase, the post-listening stage took place. At this stage students' reflection and evaluation, skills were aimed to develop though post-listening activities such as discussion, speaking and writing activities.

\section{Materials}

The following digitalized short stories were selected for the treatment; Transients in Arcadia by O. Henry, The Blue Hotel by Stephen Crane, The Fall of the House of Usher by Edgar Allan Poe, The Devil and Tom Walker, by Washington Irving and A Horseman in the Sky by Ambrose Bierce. Handouts and extra listening exercises were prepared for each digital short story and administered based on Vandergrift's pedagogical cycle. All of the digital short stories that were used in the current research were downloaded or used from various websites. Thus, the digital short stories were read and voice recorded by native speakers of English. The digital short stories were retrieved from digital platforms.

\section{Data Analysis and Results}

Data were obtained through pre-test and post-test and 6 written structured interview questions to measure the perspectives towards the use of digital short stories and digital short stories' effects on listening skills development in a preparatory class at the ELT department. The results of pre-test and post-test were analysed through SPSS program. A listening skills achievement test was administered as the pre-test and post-test those were adapted from IELTS listening practice books. A t-test was utilized to measure the difference between pre-test and post-test. Interview responses were analysed through content analysis which is a research method used to identify patterns in an oral or written record of communication. The results showed that participants' answers heavily focused on three categories and they thought that digital short stories were effective to develop these aspects. These categories are language skills development, literature related development, and cultural development. 


\section{Test Scores of the Experimental Group}

As shown in Table 1, the experimental group attained about 5 points increase between pre-test and post-test mean score.

Table 1. Results of the Listening Comprehension Test (pre and post-tests)

\begin{tabular}{|l|l|l|l|l|}
\hline Test & $\underline{\mathrm{n}}$ & $\underline{\text { Mean }}$ & $\underline{\text { Std. Dev }}$ & $\underline{\text { Cronbach's Alpha }}$ \\
\hline Pre-test & 24 & 26.51 & 2.98 & .68 \\
\hline Post-test & 24 & 31.34 & 1.68 & .67 \\
\hline
\end{tabular}

Table 2 shows that participants experienced highly effective listening skill development and there is a significant development between pre-test and post-test results. After the treatment process, there was a significant difference on behalf of the experimental group $(4.312, \mathrm{p}<.05)$.

Table 2. T-test results for the experimental group

\begin{tabular}{|l|l|l|l|}
\hline Test & $\underline{\mathrm{n}}$ & $\underline{\mathrm{t}}$ & $\mathrm{p}$ \\
\hline Pre-test & 24 & 0.415 & 0.610 \\
\hline Post-test & 24 & 4.312 & 0.000 \\
\hline
\end{tabular}

\section{Participants' perspective towards listening activities with digital short stories}

As mentioned above, content analysis was used to analyse participants' responses to a written structured interview. The qualitative data were analysed through three main categories and their sub-categories. Detailed information is provided below.

\section{First category: language skills development}

The first category was determined as language skills development because nearly all of the students related digital short stories with an aspect of language learning. According to participants, the digital short stories are so valuable to develop their vocabulary, grammar, listening and pronunciation skills. Students' mentions and their rates were presented below: 
Table 3. Language skills development mention rate

\begin{tabular}{|l|l|c|}
\hline$\underline{\text { N. }}$ & Items & Total Mentions \\
\hline 1 & Beneficial to improve listening skills & 20 \\
\hline 2 & Support vocabulary acquisition through the context & 16 \\
\hline 3 & Helpful to spell and pronounce unknown vocabularies correctly & 10 \\
\hline 4 & Helpful to gain familiarity with complex grammar structures & 5 \\
\hline 5 & Pronunciation development & 23 \\
\hline
\end{tabular}

As Table 1 presents all of the participants thought that digital short stories were useful for pronunciation development. The item was mentioned 23 times in students' interviews. The second highly mentioned item was 'beneficial to improve listening skills' which has 20 mentions. It showed that participants were satisfied with digital short stories and prepared teaching materials. Additionally, they thought that these digital short stories supported their vocabulary acquisition because of the rich context of literary texts. Besides, they thought that these short stories presented complicated grammatical structures and made them familiar with these structures. Few of participants' responses to interview questions are presented below:

Firstly, digital short stories contributed a number of benefits to our listening exercises because these short stories were so interesting and attractive. So, when I listened to these short stories, I enjoyed and wanted to listen again. Additionally, these short stories helped to improve our listening skills owing to effective pronunciation (S. 1).

Yes, these stories exactly improve my pronunciation (S. 2).

They are beneficial for us. For example, at the beginning of this year, I couldn't understand listening activities, now I can generally understand them (S. 3).

After we listened to stories, there were questions and activities about them and they helped me improved my listening in detail skills (S. 4).

\section{Second category: literature related development}

The second category was determined as literature related development of participants because the teaching materials were chosen among well-known American short stories of famous writers. For this reason, teaching materials were expected to develop participants' perceptions towards literary texts, narration, genre, and style. As expected participants presented detailed data about the second category which is presented below through table 2 . 
Table 4. Literature related development

\begin{tabular}{|c|l|c|}
\hline N. & Items & Total Mentions \\
\hline 1 & Focus on gist, content, and details & 21 \\
\hline 2 & Satisfied with the theme, topic, and plot & 18 \\
\hline 3 & Eager to learn American literature & 20 \\
\hline 4 & Recommend digital short stories for listening activities & 20 \\
\hline 5 & Interesting and exciting listening exercises & 15 \\
\hline
\end{tabular}

As table 2 presents, nearly all of the participants mentioned that they could easily focus on short stories' gist, interesting details and they were satisfied with the content. Hence, 'focus on gist, content and details' item was mentioned 21 times in participants' interview responses. Other mostly repeated items were 'Eager to learn American literature' and 'Recommend digital short stories for listening activities' that reveal participants were eager to listen to more digital short stories for listening exercises and these short stories made them more eager to learn literature. As the participants were student-teachers of English, hopefully, they will implement such classroom applications into their future classrooms as well. Additionally, this inference was supported by other two items which are 'Satisfied with the theme, topic, and plot' and 'Interesting and exciting listening exercises' because these items were repeated 18 and 15 times in interview responses of participants. Few of participants' answers are presented below:

Yes, I like American writers because their minds were powerful and impressive. Also, I like themes, plot, and topics of digital short stories. Teachers should use these stories for listening activities (S. 1).

I like the topic of each story because stories are exciting and draw my attention. Language teachers should use these stories to make listening more enjoyable (S. 2).

I think stories are funny, exciting and topics of stories different from each other (S. 3).

\section{Third category: cultural development}

As it is a well-known fact, cultural elements are mostly conveyed and presented in a nation's literature, art, history, songs, and language, etc. So, short stories whether they are written, oral or digital include a nation's cultural figures and elements. For this 
reason, the third category is determined as cultural development. The third category includes three items which are 'discovering other cultures', 'Being aware of cultural differences between their own culture and others' and 'empathy'. The results of the third category are presented by table 3 below:

Table 5. Results for cultural development

\begin{tabular}{|c|l|c|}
\hline N. & Items & Total Mention \\
\hline 1 & Discovering other cultures & 20 \\
\hline 2 & $\begin{array}{l}\text { Being aware of cultural differences and similarities } \\
\text { between their own culture and others }\end{array}$ & 15 \\
\hline 3 & Empathy & 10 \\
\hline
\end{tabular}

The results for 'discovering other cultures' indicated that participants were aware of discovering other cultures through digital short stories because the item was repeated 20 times in their responses to interview questions. Additionally, participants were aware of the fact that each culture is unique and quite different from each other even if they have some similarities. The item 'Being aware of cultural differences and similarities between their own culture and others' was mentioned 15 times in participants' responses. The last item of the third category is 'empathy' which was repeated 10 times. Some students mentioned as if they had been the character of stories which show they developed their empathy skills. Few of students' responses are presented below:

These stories are useful to understand cultural things from America and its history because there are lots of details in these stories (S. 1).

When I listen to a short story I generally think like that what I would do in that case. Sometimes, I get really excited (S. 2).

Some of the stories inform us about American history or racism, after these activities I do some search about details. I'm really fond of history (S. 3).

The data of the current study analysed by using content analysis and three categories were created to analyse the data efficiently. The first category 'language skills development' includes 5 different items. The second category 'Literature related development' includes 5 different items and the third category 'cultural development' includes 3 items. The results for each item of categories were presented above in details. In general, the results indicate that student teachers of English who study at preparatory classrooms are quite satisfied with the treatment process in different aspects. Participants thought that digital short stories developed their language skills especially pronunciation, grammar, and vocabulary. 
Besides, they thought that digital short stories provided useful and exciting information about different cultures. Additionally, they stated that these short stories made them more curious to learn more about other cultures. As Brown (2001) stated that listening to stories not only stimulates our senses but also it challenges our minds. So, minimizing the effects of digital short stories to learning and experiencing literature would be unfair.

\section{Conclusion and pedagogical implications}

Through the present study's treatment phase participants were encouraged to grasp the meaning of digital short stories by using a combination of both the bottom-up and top-down approaches. As previously mentioned, digital short stories were selected and additional teaching materials were prepared suitable for these approaches. As a novel approach to developing listening skills digital short stories offers language learners listening practice, cultural awareness and sense of literature. Digital short stories are used for various teaching purposes. Firstly, it provides quality teaching content and lessons to students who need to develop listening skills. Language teachers are able to reach a wide range of digital short stories through the internet, online libraries, various websites, and applications. Additionally, language teachers can read short stories loudly and record their voices through voice recording applications and then they can add extra videos, pictures and comprehension questions to their own digital short stories.

They can digitalize short stories by technological tools and make them more interactive and effective for listening skills. Besides, the availability of different variants of digital short stories allows language teachers to select and provide language learners with a suitable sort that fit both their level and interests. As Gjuzeleva (2015) stated that language teachers need no expert skills to use literature in language classrooms. Additionally, language classrooms have become more interactive and communicative that using literary text for only to read, retell or translate would be an error. On the contrary, these extremely rich texts and their valuable content should be used to develop students' cultural awareness and understanding, should serve as an initiator for a discussion, evoke language learners' imagination and develop their language skills (Gjuzeleva, 2015). Language teachers should be trained on how to use and integrate literary texts into their teaching materials through in-service training. If the benefits and gains of using literary texts explained enough, they will eventually use them.

Moreover, digital short stories are alternative teaching sources to enhance the learning capacity of learners who have different learning styles. Similar to Verdugo and Belmonte's (2007) point of view, including graphics, pictures, sound effects in digital short stories enhances both students' attention and motivation towards oral 
input in foreign language classrooms. Additionally, being exposed to digital short stories made participants more engaged and active during the treatment phase. The results made us able to answer research questions of the study; digital short stories are effective to develop the listening skills of participants. Besides, the participants have positive attitudes towards using these materials in foreign language classrooms. Thus, participants of the present study were student teachers of English, they may utilize digital short stories in their teaching profession as well. Moreover, the treatment phase provided an effective application of these content rich materials.

In a nutshell, digital short stories should be used to foster listening skills, communicative skills, language skills and cultural awareness of language learners. The current research shed light on how to use digital short stories to develop listening skills through digital short stories due to basic approaches of this area. However, digitalized short story research can be conducted in other areas as well. 


\section{References}

Abdollahpour, Z. \& Asaszadeh, N. (2012). The impact of exposure to digital flash stories on Iranian EFL learners' written reproduction of short stories. Canadian Journal on Scientific and Industrial Research, 3(2), 40-53.

Abidin, M. J. Z., Pour Mohammadi, M., Souriyavongsa, T., Da, C. \& Ong, L. K. (2011). Improving listening comprehension among Malay preschool children using digital stories. International Journal of Humanities and Social Science, 1(14), 159-164.

Abou Shaban, S. S. (2015). The effects of digital storytelling, storytelling and storyreading on enhancing Palestinian ninth graders' paragraph writing skills. European Journal of Educational Studies, 7(1), 23-34.

Anderson, A. \& Lynch, T. (2003). Listening. Oxford: Oxford University.

Baki, Y. (2015). Dijital öykülerin altıncı sınıf öğrencilerinin yazma sürecine etkisi. Unpublished doctoral dissertation, Ataturk University, Institute of Education Sciences, Erzurum, Turkey.

Brown, J. E. (2001). Learning through Listening Strategies for Literature. Language Arts Journal of Michigan,17(2), 14-17.

Buck, G. (2001). Assessing listening. Cambridge: Cambridge University.

Chuang, W. T., Kuo, F. L., Chiang, H. K., Su, H. Y. \& Chang Y. H. (2013). Enhancing reading comprehension and writing skills among Taiwanese young EFL learners using digital storytelling technique. 21st International Conference on Computers in Education. Indonesia: Asia-Pacific Society for Computers in Education.

Ciğerci, F. M., \& Gultekin, M. (2017). Use of digital stories to develop listening comprehension skills. Issues in Educational Research, 27(2), 252-268.

Cook, V. (1996). Second Language Learning and Language Teaching. London: Arnold.

Çıralı, H. (2012). Dijital hikâye anlatımının görsel bellek ve yazma becerisi üzerine etkisi. Unpublished master's dissertation, Hacettepe University, Ankara.

Foley, L. M. (2013). Digital storytelling in primary-grade classrooms. Unpublished doctoral dissertation. Arizona State University, Phoenix, Arizona.

Gough, CH. (1993). Teaching Listening Skills - lecture on Nov. 28, 1993. Quoted in Hrehovčík, T.; Uberman, A. 2003. English Teaching Methodology: An Undergraduate Course for EFL Trainees. Rzeszow: Wydawnictwo Uniwersytetu Rzeszowskiego, 2003. p. 150. 
Graham, S. (2006). Listening Comprehension: The Learners' Perspective. System, 34, 165-182. Güleç, S. \& Durmuş, N. (2015). A Study Aiming to Develop Listening Skills of Elementary Second Grade Students. Procedia - Social and Behavioral Sciences, 191, (2015), 103-109.

Gjuzeleva, S. (2015). Getting Students Lit Up: Teaching English Through Literature. Годишник На Департамент, Англицистика, 19-37.

Hansan, A. (2000). Learners' perceptions of listening comprehension problems. Language, Culture and Curriculum, 13, 137-152.

Hassen, D. (2016). The Influence of Podcasts on EFL Student's Listening Comprehension. Unpublished Master's Thesis, University Mohamed Kheider of BISKRA, Algeria.

Ibtisam Ali, H. B. (2016). Review of Vandergrift's Pedagogical Cycle (2003b) As New Development in Teaching Listening to EFL Learners. Journal of Teaching and Education, 5 (1), 459-465.

Jimmy, A. L. (2013). The Effectiveness of Digital Stories on Listening Comprehension. Unpublished Master's Thesis, Universiti Teknologi, Malaysia.

Jones, L. C. (2008). Listening comprehension technology: Building the bridge from analog to digital. CALICO Journal, 25(3), 400-419.

Kledecka-Nadera, A. (2001). Application of computer-assisted language learning in the development of reading comprehension skills. Poznan. Retrieved from http:// ifa.amu.edu.pl/fa/files/ifa/papers/kledecka/kledecka-mgr.pdf

Kline, J. A. (1996). Listening Effectively. Washington: Air University.

Krashen,S.D. (1985). The Input Hypothesis. London: Longman.

Küçükoğlu, H. \& Sariçoban, A. (2011). Using Literature in EFL Classes: Short Story. In 1st International Conference on Foreign Language Teaching and Applied Linguistics FLTAL 2011 Proceedings Book (160-170). Sarajevo: FLTAL.

Lindsay, C. \& Knight, P. (2006). Learning and teaching English: A course for teachers. Oxford: Oxford University.

Lundsteen, S.W. (1979). Listening; it's Impact on All Levels on Reading and the Other Language Arts. Urbana, IL: National Council of Teachers of English \& ERIC clearing house on reading and communication skills.

Mendelson, D. J. (1994). Learning to listen. USA: Dominie. 
Ofsted (2011). Modern Languages. Achievement and challenge 20072010. Retrieved from http://www.ofsted.gov.uk/resources/modern-languages-achievement-andchallenge2007-2010

Piaget, J. (1970). Science of education and the psychology of the child. New York: Viking

Rivers, V. M. (1992). Communicating Naturally in a Second Language. Cambridge: Cambridge University.

Rost, M. (1994). Introducing listening. London: Penguin.

Rost, M. (2002). Teaching and Researching Listening. London: Longman.

Smidt, E \& Hegelheimer, V. (2004). Effects of online academic lectures on ESL listening comprehension, incidental vocabulary acquisition, and strategy use. Computer Assisted Language Learning, 17(5), 517-556.

Tamjid, H. N. \& Hassanzadeh, L. (2012). The Effect of Digital Stories on Enhancing Iranian Pre-intermediate EFL Learners' Listening Comprehension. The Journal of Applied Linguistics, 5(11), 29-44.

Verdugo, D. R. \& Belmonte, I. A. (2007). Using digital stories to improve listeningcomprehension with Spanish young learners of English. Language Learning \& Technology, (11)1, 87-101.

Vandergrift, L. (2004). Listening to learn or learning to listen? In Cambridge University Press (Ed.). Annual Review of Applied Linguistics, 3-25. Cambridge University Press, USA.

Vandergrift, L. (2007). Recent development in second language listening comprehensionresearch. In Graeme Porte (Ed.). Language Teaching Surveys and Studies, (pp. 210-291). Canada:Cambridge University.

Yilmaz, A. (2015). Short stories via computers in EFL classrooms: An empirical study forreading and writing skills. Reading Matrix: An International Online Journal, 15(1), 41-53.

Warschauer, M., \& Healey, D. (1998). Computers and language learning: An overview. Language Teaching, 31, 57-71.

Wolvin, A., Coakley, C. (1991). A Survey of the Status of Listening Training in Some Fortune 500 Corporations. Communication Education, USA. 


\section{Author}

* Zeynep Çetin Köroğlu has been working as an Assistant Professor Doctor at English Language Teaching Department of Bayburt University, Turkey. Her academic background mainly consists of English Language Teaching. She graduated from Gazi University and got her MA degree. Then, she started her $\mathrm{PhD}$ at the same university and completed it in 2015. She especially interested in intercultural communication, language teachers' education, ICT implementations in language pedagogy and language assessment. She published numerous book chapters and articles related with her research interests.

ORCID: https://orcid.org/0000-0002-9456-8910

How to reference this article: Çetin Köroğlu, Z. (2020). Effects of Digital Short Stories on the Development of Listening Skills: An Action Research. GIST - Education and Learning Research Journal, 20, 65-84. https://doi.org/10.26817/16925777.766 